ważny element działalności na rzecz uzyskiwania przewagi konkurencyjnej firmy. Oznacza to tworzenie organizacji, w której zdobywanie nowej wiedzy nie stanowi domeny wąskiej grupy specjalistów, ale staje się integralnym składnikiem każdego zajęcia, zwyczajnym trybem postępowania i zadaniem każdego pracownika (Nonaka, 2006, s. 29). W tym procesie ważną rolę przypisuje się właściwej organizacji systemu pozyskiwania i transferu wiedzy w przedsiębiorstwie. Jednocześnie zaprezentowane wyżej studium przypadku jest dobrym przykładem zastosowania metodyki właściwej dla procesu edukacji osób dorosłych. Warto przy tym zwrócić uwagę na wzajemne związki zachodzące między teorią i praktyką edukacyjną, której przykładem jest zaprezentowane wyżej studium.

\title{
Bibliography
}

Edvison, L., Malone, M.S. (2001). Kapitał intelektualny. Warszawa: PWN.

Knowles, M.S., E.F. Holton, R.A. (2009). Swanson Edukacja dorosłych. Warszawa: PWN.

Kuc, B.R., Żemigała M. (2010). Menedżer nowych czasów. HELION. Gliwice.

Matthews, J.J., D. Magginson, Surtees M. (2008). Rozwój zasobów ludzkich. HELION. Gliwice.

Obora, H. (2010). Podejscie PDCA Problem Solving w rozwiazywaniu problemów organizacji. W: Acta universitatis lodziensis, Folia oeconomica. 234.

УДК 378:7.012

DOI: https://doi.org/10.35387/od.2(16).2019.122-130

Торчевська Наталя Вікторівна - кандидат педагогічних наук, вчений секретар Київської державної академії декоративно-прикладного мистецтва і дизайну імені Михайла Бойчука

ORCID ID: https://orcid.org/0000-0002-0995-5335

E-mail: Smolianaya2008@ukr.net

\section{ФОРМУВАННЯ ХУДОЖНЬОГО СМАКУ СТУДЕНТІВ МИСТЕЦЬКИХ СПЕЦІАЛЬНОСТЕЙ У ПРОЦЕСІ ВИВЧЕННЯ КУРСУ «ІСТОРІЯ МИСТЕЦТВ»}

\begin{abstract}
Анотація. У публікації на основі загальнонаукових методів: аналізу, синтезу, порівняння та узагальнення визначено сутність поняття «художній смак» та виокремлено форми роботи з формування художнього смаку студентів митецьких спеціальностей у процесі вивчення курсу "/сторія мистецтв». "Художній смак» - це складна інтегративна якість особистості, основа розвитку духовності та активно-творчої їі діяльності; здатність до сприймання, аналізу й естетичного оцінювання творів мистецтва відповідно до сфрормованих ідеальних переконань про прекрасне. Художній смак особистості виявляється у процесі естетичного оцінювання, під час висловлювання
\end{abstract}


власних суджень щодо творів мистецтва керуючись естетичними почуттями, потребами, світоглядом та знаннями. Передусім формування художнього смаку студентів мистецьких спеціальностей залежить від успішного оволодіння знаннями з курсу «Історія мистецтв», а також від налагодження міжпредметних зв'язків із циклом фахових дисциплін. Так, студенти набувають системних знань про виникнення та історичний розвиток основних видів, жанрів мистецтва; розуміння особливостей художніх стилів; вивчення кращих зразків світового мистецтва, їх сприймання, аналіз і оцінювання відповідно до ідеальних уявлень про прекрасне, що $\epsilon$ основою фоормування художнього смаку. Виокремлено фрорми і методи роботи з формування художнього смаку студентів мистецьких спеціальностей у процесі вивчення курсу «Історія мистецтв»: аналіз творів мистецтв за спеціальним алгоритмом; створення ілюстрованих словників мистецтвознавчих термінів, понять, напрямів мистецтва; виступи з підготовленими презентаціями (метод ілюстрації); застосування інформаційнокомунікаційних технологій (методи спостереження $і$ ілюстрації); відвідування музеїв мистецтва, персональних виставок, екскурсії до пам'яток архітектури, творчі зустрічі (словесні і наочні методи: бесіда, дискусія, спостереження, ілюстрація); відвідування екзаменаційних переглядів; відвідування екзаменаційних переглядів, виконання практичних форм роботи (методи графрічних вправ, замальовки).

Ключові слова: історія мистецтв, художній смак, мистецька освіта, естетичне виховання.

Torchevska Natalia - Candidate of Pedagogical Sciences, Scientific Secretary of the Kyiv State Academy of Arts and Design named after Mykhailo Boychuk

ORCID ID: https://orcid.org/0000-0002-0995-5335

Email: Smolianaya2008@ukr.net

\title{
FORMATION OF ARTISTIC TASTE OF STUDENTS OF THE ARTS SPECIALISTS IN THE PROCESS OF STUDY OF THE «HISTORY OF ARTS» COURSE
}

\begin{abstract}
The publication on the basis of general scientific methods: analysis, synthesis, comparison and generalization, defines the essence of the concept of "artistic taste» and identifies forms of work on the formation of artistic taste of students of art specialties in the course of studying the course "History of Arts». "Artistic taste» is a complex integrative quality of the person, the ability to perceive, analyze and aesthetically evaluate works of art in accordance with the formed ideal ideas about the beautiful, which leads to the development of spirituality and its active creative activity. The artistic taste of the individual is manifested in the process of aesthetic evaluation, in the expression of their own judgments of works of art, guided by aesthetic feelings,
\end{abstract}


needs, outlook and knowledge. First of all, forming the artistic taste of art students depends on the successful acquisition of knowledge in the course "History of Arts», as well as the establishment of cross-curricular links with the cycle of professional disciplines. Thus, students acquire systematic knowledge about the origin and historical development of the main types, genres of art; understanding of features of artistic styles; the study of the best examples of world art, their perception, analysis and evaluation in accordance with the ideal ideas about the beautiful, which is the basis for the formation of artistic taste. Forms and methods of work on forming the artistic taste of students of artistic specialties in the course of studying the course "History of Arts» are distinguished: analysis of works of arts by a special algorithm; creation of dictionaries of art criticism terms, concepts, directions of art; presentations with prepared presentations (illustration method); application of information and communication technologies (methods of observation and illustration); visiting art museums, solo exhibitions, sightseeing tours, creative meetings(verbal and visual methods: conversation, discussion, observation, illustration); attending examinations; attending examinations, performing practical forms of work (methods of graphic exercises, sketches, sketches, etc.).

Key words: art history, artistic taste, art education, aesthetic education.

Постановка проблеми, її актуальність. У сучасних умовах модернізації системи вищої освіти України актуальним є пошук умов, що сприятимуть оптимізації якості профресійної підготовки студентів мистецьких спеціальностей. Під якістю такої підготовки мається на увазі не просто підготовка професійного мистця, а формування високодуховної особистості, з розвиненим рівнем художньої та естетичної культури, здатної до глибинного аналізу специфріки і художніх особливостей творів мистецтва; до творчого самостійного створення мистецького продукту; що володіє професійною майстерністю і художнім смаком.

Аналіз останніх досліджень і публікацій. Наше вивчення показало, що проблема смаку та його різновидів (естетичного, художнього, музичного) висвітлено у науковому доробку вітчизняних науковців: Бабенко Т., Джоли Д., Комаровської О., Левчук Л., Мережко Ю., Румянцевої С., Щербо А. Незважаючи на наявність численних досліджень з різних аспектів формування художнього (естетичного) смаку, нами не виявлено усталеного визначення науковцями поняття «художній смак». Вченими не виокремлюються форми, методи роботи з формування художнього смаку студентів мистецьких спеціальностей у процесі вивчення історії мистецтв, що й зумовило вибір теми нашої публікації.

Мета статті -на основі загальнонаукових методів: аналізу, синтезу, порівняння та узагальнення визначити сутність поняття «художній смак» та виокремити фрорми роботи з формування художнього смаку студентів митецьких спеціальностей у процесі вивчення курсу з історії мистецтв.

Виклад основного матеріалу дослідження. Метою вивчення 
навчальної дисципліни «Історія мистецтв» $€$ формування у студентів мистецьких спеціальностей системних знань про виникнення та історичний розвиток основних видів та жанрів мистецтва у різних народів світу; розуміння особливостей художніх стилів; знайомство з кращими зразками світового мистецтва, їх самостійний і колективний аналіз.

На думку Мережко Ю. та Румянцевої С., високий художній смак частково є природженим для людей, частково ж виховується упродовж тривалого часу красою природи та завдяки прекрасним, істинним витворам мистецтва (музики, живопису, словесності, театру) (Мережко, Румянцева, 2018 , с. 258). Цінною для нашого дослідження є думка Комаровської О., що художній (естетичний) смак людина оприлюднює переважно через судження, в яких висловлює оцінку художніх творів відповідно до власних естетичних почуттів, потреб, інтересів, світогляду. Тобто, сформованість художніх смаків виявляється через глибину індивідуальної оцінки, яка візуалізується в судженнях різного ступеню обґрунтованості, але завжди спираються на почуття і привласнення певної цінності, яка перебуває в ареалі сфрормованого художнього смаку (Комаровська, 2018, с. 10).

Виходячи $з$ окресленого вище, зауважимо, що вивчення дисципліни «Історія мистецтв» сприяє формуванню у студентів художнього смаку, власного мистецького бачення й мотивації до навчально-творчої діяльності, естетичного світосприйняття, естетичних потреб тощо.

Насамперед зауважимо, що у науковому обігу нами не знайдено одностайного визначення поняття «художній смак». Здебільшого зміст та структура цього поняття науковцями трактується по-різному (табл. 1).

Таблиця 1

Сутність поняття «художній смак» за різними джерелами

\begin{tabular}{|c|c|}
\hline $\begin{array}{c}\text { Назва } \\
\text { дефрініції }\end{array}$ & Визначення, автор \\
\hline $\begin{array}{l}\text { Художній } \\
\text { смак }\end{array}$ & $\begin{array}{l}\text { інтегративна якість особистості, в якій відображено знання, } \\
\text { уміння і художньо-ціннісні орієнтації, що зумовлюють } \\
\text { сприймання і оцінювання творів образотворчого мистецтва } \\
\text { (Паруніна, 2009, с. 21). }\end{array}$ \\
\hline $\begin{array}{l}\text { Професійни } \\
\text { й художній } \\
\text { смак }\end{array}$ & $\begin{array}{l}\text { складна комплексна якість особистості, що являє собою } \\
\text { єдність теоретичної і практичної підготовленості до сприймання } \\
\text { й оцінювання творів, предметів, явищ, ситуацій дійсності й } \\
\text { мистецтва з позицій художньо-естетичного ідеалу (Лушина, } \\
2012 \text {, с. 20). }\end{array}$ \\
\hline $\begin{array}{l}\text { Художній } \\
\text { смак як } \\
\text { різновид } \\
\text { естетичного }\end{array}$ & $\begin{array}{l}\text { є однією з найважливіших характеристик становлення } \\
\text { людини, що відбиває рівень ії самовизначення в мистецтві; } \\
\text { фактично, це здатність людини робити вибір та оцінювати, яка } \\
\text { ґрунтується на відчутті задоволення від споглядання певного } \\
\text { мистецького об'єкта. «Художній смак» віддзеркалює присвоєння } \\
\text { людиною певної мистецької цінності як стійкого вибору, постає } \\
\text { як здатність особистості до індивідуального відбору мистецьких }\end{array}$ \\
\hline
\end{tabular}




\begin{tabular}{|c|c|}
\hline & $\begin{array}{l}\text { цінностей, а тим самим - до саморозвитку і самовиховання. } \\
\text { Відтак, художній смак - це основа для формування у людини } \\
\text { здатності естетичної оцінки. Зауважимо: художній смак } \\
\text { людини, як більш-менш стійке утворення, динамічно } \\
\text { розвивається, збагачується, що, безумовно, залежить від } \\
\text { розширення кола художнього пізнання і міри сформованості } \\
\text { інтересів (Комаровська, 2018, с. 8-9). }\end{array}$ \\
\hline $\begin{array}{l}\text { Художній } \\
\text { смак }\end{array}$ & $\begin{array}{l}\text { Основна категорія естетичної свідомості особистості, що } \\
\text { виражає її здатність до адекватної раціонально-емоційної } \\
\text { оцінки творів мистецтва у відповідності } 3 \text { ідеальними } \\
\text { уявленнями про прекрасне і спонукає до активно-творчої } \\
\text { діяльності (Мережко, Румянцева, } 2018, \text { с. } 265-266) \text {. }\end{array}$ \\
\hline $\begin{array}{l}\text { Художній } \\
\text { смак }\end{array}$ & $\begin{array}{l}\text { визначається своєрідністю почуттєвої сфери людини та її } \\
\text { освіченістю, зокрема мистецькою, естетичним досвідом, тобто є } \\
\text { відносно сталим особистісним утворенням. Свій художній } \\
\text { (естетичний) смак людина оприлюднює переважно через } \\
\text { судження, в яких висловлює оцінку художніх творів відповідно } \\
\text { до власних естетичних почуттів, потреб, інтересів, світогляду } \\
\text { (Левчук, } 2010 \text {, с. } 60-65) \text {. }\end{array}$ \\
\hline
\end{tabular}

Отже, на основі аналізу визначень за різними науковцями поняття «художній смак» викладених нами у таблиці 1, можемо зробити висновок, що в науковому обігу це поняття не має загальноприйнятого визначення. Науковці трактують поняття «художній смак» як інтегративну якість особистості, категорію естетичної свідомості особистості, різновид почуттєвої сфери тощо. Спільним у визначеннях науковців $€$ те, що наявність розвиненого художнього смаку залежить від сприймання і оцінювання творів образотворчого мистецтва відповідно до ідеальних уявлень про прекрасне, що спонукає до активно-творчої діяльності.

Виходячи з окресленого вище, можна стверджувати, що «художній смак» - це складна інтегративна якість особистості, здатність до сприймання, аналізу й естетичного оцінювання творів мистецтва і архітектури відповідно до сформованих ідеальних уявлень про прекрасне, що спонукає до розвитку духовності та активно-творчої її діяльності. Художній смак особистості виявляється у процесі естетичного оцінювання, висловлювання власних суджень і оцінювання творів мистецтва керуючись естетичними почуттями, потребами, інтересами, світоглядом та знаннями. Передусім формування художнього смаку студентів мистецьких спеціальностей залежить від успішного оволодіння знаннями з курсу «Історія мистецтв», а також від налагодження міжпредметних зв'язків із циклом фахових дисциплін. Цьому зокрема сприятимуть відповідні форми і методи навчальної роботи, використання комплексу навчальнометодичного забезпечення, інформаційно-комунікаційних технологій тощо.

Бірюковим М. представлено класифрікацію різновидів художнього смаку як однієї зі складових його формування з урахуванням поглядів науковців на це питання і культурно-історичних умов його виникнення. На 
переконання науковця, гарний художній смак виявляє людина, яка не лише насолоджується красою форми і відчуває їі виразність, але й розуміє їі невідповідність ідейно-художньому змісту твору. Смак виявляється у почутті співмірності і гармонії, в почутті міри у всьому, що виготовляє і споживає людина. Кожне порушення міри - як у бік надмірності, так і в бік недостачі - $є$ антиестетичним феноменом, породжує відчуття потворного та естетичної неповноцінності. Відсутність художнього смаку в підсумку може зумовити й відсутність гуманності (Бирюков, 2013, с. 12-13).

Основні форми і методи, що сприяють формуванню художнього смаку в студентів мистецьких спеціальностей у процесі вивчення курсу історії мистецтв, їх сутність викладено нами в таблиці 2.

Таблиця 2

Форми і методи навчання з формування художнього смаку студентів мистецьких спеціальностей у процесі вивчення курсу історії мистецтв

\begin{tabular}{|c|c|}
\hline $\begin{array}{r}\text { Форм } \\
\text { нав } \\
\text { рс }\end{array}$ & Зміст роботи \\
\hline $\begin{array}{l}\text { Аналіз твору } \\
\text { мистецтва }\end{array}$ & $\begin{array}{l}\text { форма роботи, що уможливлює виявлення аналітичних } \\
\text { умінь студента: аналізувати, описувати, визначати } \\
\text { належність до відповідного напряму мистецтва, } \\
\text { стилістичних особливостей. Аналіз слід проводити за } \\
\text { планом, визначаючи: назву твору та ім'я автора; жанр; вид } \\
\text { живопису (станковий, монументальний, декоративний) / } \\
\text { скульптури (рельєф чи кругла (монументальна чи } \\
\text { монументально-декоративна)), архітектури; тему та ідею } \\
\text { твору; стиль, хронологічні межі створення; сюжет, зміст } \\
\text { твору. композицію і колорит; манеру письма; аналіз } \\
\text { деталей;власне оцінювання твору; інтерпретацію. }\end{array}$ \\
\hline $\begin{array}{l}\text { Створення } \\
\text { ілюстрованих } \\
\text { словників } \\
\text { мистецтвознавч } \\
\text { их термінів, } \\
\text { понять, } \\
\text { напрямів } \\
\text { мистецтва }\end{array}$ & $\begin{array}{l}\text { У процесі створення таких словників студенти на основі } \\
\text { опрацювання видань з історії мистецтва та літератури, } \\
\text { рекомендованої для вивчення курсу опрацьовують систему } \\
\text { понять мистецьких термінів, що сприяє закріпленню і } \\
\text { систематизації цілісних наукових знань, які є теоретичним } \\
\text { підґрунтям у підготовленості до естетичного сприймання і } \\
\text { оцінювання творів мистецтва, формування художньо- } \\
\text { естетичних ідеалів тощо. }\end{array}$ \\
\hline $\begin{array}{l}\text { Виступи з } \\
\text { підготовленими } \\
\text { презентаціями } \\
\text { (метод } \\
\text { ілюстрації) }\end{array}$ & $\begin{array}{l}\text { Передбачають підготовку студента за відповідною темою з } \\
\text { детальним аналізом витворів мистецтва, представлених на } \\
\text { слайдах презентації. Водночас студент може висвітлювати } \\
\text { біографію і її зв'язок з творчою реалізацію мистця, } \\
\text { висловлюючи власні погляди на творчість і внесок автора до } \\
\text { історії мистецтв. }\end{array}$ \\
\hline & $\begin{array}{l}\text { Йдеться про створення у тематичному пабліку тематичних } \\
\text { постів у соціальній мережі Facebook, використання }\end{array}$ \\
\hline
\end{tabular}




\begin{tabular}{|c|c|}
\hline $\begin{array}{l}\text { и } \\
\text { реже } \\
\text { аціiі) }\end{array}$ & $\begin{array}{l}\text { скрайбінгу, веб-квестів, користування } \\
\text { платформами з вивчення історії мистецтва, відвідування } \\
\text { віртуальних бібліотек, музеїв, галерей, мистецького проекту } \\
\text { Google тощо. Інформаційно-комунікаційні технології дають } \\
\text { змогу відвідати віртуальні музеї і галереї найвіддаленіших } \\
\text { країн світу, детально ознайомившись із архітектурними та } \\
\text { скульптурними особливостями споруд, оволодіти } \\
\text { інформацією від провідних мистецтвознавців, лекторів } \\
\text { найпрестижніших навчальних закладів світу, створити і } \\
\text { обговорити в режимі online запропоновані викладачем тем з } \\
\text { предмету тощо (Торчевська Н., 2019, с. } 70-71) \text {. }\end{array}$ \\
\hline $\begin{array}{l}\text { дування } \\
\text { в } \\
\text { ецтва, } \\
\text { ональних } \\
\text { вок, } \\
\text { рсії до } \\
\text { ток } \\
\text { ектури, } \\
\text { і зустрічі } \\
\text { есні і } \\
\text { іі методи) }\end{array}$ & $\begin{array}{l}\text { Форми роботи, що не тільки впливають на мотивацію } \\
\text { студентів до творчо-навчальної діяльності, а і сприяють } \\
\text { збагаченню їхнього духовного світу, ерудиції, розвитку } \\
\text { інтелекту і емоційних запитах, моральності, мистецьких } \\
\text { уподобань, що є важливими для формування художнього } \\
\text { смаку. } \\
\text { Водночас відвідування музеїв спонукає до пробудження } \\
\text { естетичних потреб майбутніх митців (духовно-естетичних } \\
\text { почуттів). }\end{array}$ \\
\hline уваню & $\begin{array}{l}\text { орма роботи, що забезпечує міжпредметні зв'язки курсу } \\
\text { горії мистецтв з фраховими дисциплінами. Саме на } \\
\text { заменаційних переглядах студенти мають змогу здійснити } \\
\text { Імооцінювання власних творчих робіт, висловити думку } \\
\text { одо умінь творчо підходити до поставлених завдань } \\
\text { леги, замислитися щодо інтерпретації виконаних завдань } \\
\text { проаналізувати рівень професійної майстерності. }\end{array}$ \\
\hline $\begin{array}{l}\text { ии на } \\
\text { их столах, } \\
\text { еренціях } 3 \\
\text { вь } \\
\text { ецтва }\end{array}$ & $\begin{array}{l}\text { У процесі обговорення мистецьких тем, дискусій критичного } \\
\text { характеру, ознайомлення } 3 \text { думкою } \\
\text { мистецтвознавців, критиків у пресійних } \\
\text { здатність до оцінювання, особисті ставлення до творів тощо. }\end{array}$ \\
\hline $\begin{array}{l}\text { миччні } \\
\text { ми роботи } \\
\text { оди } \\
\text { ічних } \\
\text { в, } \\
\text { Ільовки, } \\
\text { ер, } \\
\text { ерна } \\
\text { тика) }\end{array}$ & 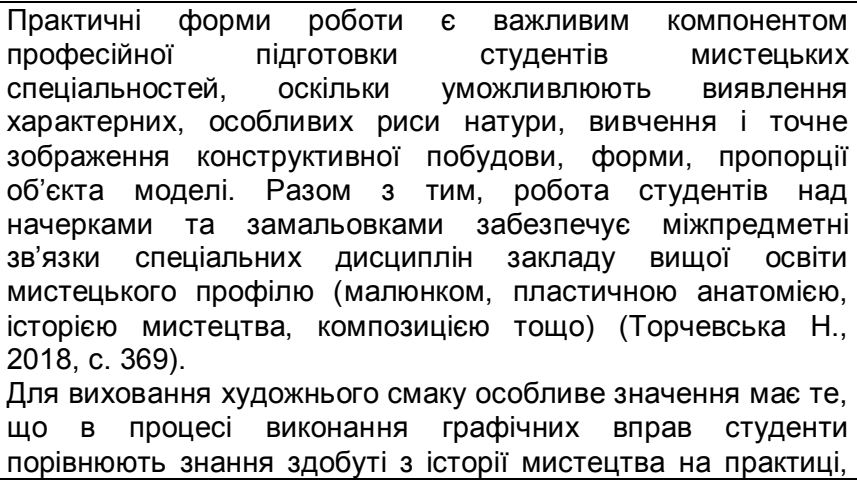 \\
\hline
\end{tabular}


Висновки та перспективи подальших досліджень. Отже, «художній смак» - це складна інтегративна якість особистості, здатність до сприймання, аналізу й естетичного оцінювання творів мистецтва і архітектури відповідно до сформованих ідеальних уявлень про прекрасне, що спонукає до розвитку духовності та активно-творчої її діяльності. Художній смак особистості виявляється у процесі естетичного оцінювання, висловлювання власних суджень і оцінювання творів мистецтва керуючись естетичними почуттями, потребами, інтересами, світоглядом та знаннями. Формування художнього смаку студентів мистецьких спеціальностей залежить від успішного оволодіння теоретичними знаннями з курсу «Історія мистецтв», налагодження міжпредметних зв'язків із циклом фахових дисциплін. У процесі вивчення історії мистецтв студенти набувають системних знань про виникнення та історичний розвиток основних видів, жанрів мистецтва; розуміння особливостей художніх стилів; вивчення кращих зразків світового мистецтва, їх сприймання, аналіз і оцінювання відповідно до ідеальних уявлень про прекрасне, що є основою формування художнього смаку. Формами і методами роботи з формування художнього смаку студентів мистецьких спеціальностей у процесі вивчення курсу «Історія мистецтв» $є$ : аналіз творів мистецтв за спеціальним алгоритмом; створення ілюстрованих словників мистецтвознавчих термінів, понять, напрямів мистецтва; виступи з підготовленими презентаціями (метод ілюстрації); застосування інформаційно-комунікаційних технологій (методи спостереження і ілюстрації); відвідування музеїв мистецтва, персональних виставок, екскурсії, творчі зустрічі; відвідування екзаменаційних переглядів; Відвідування екзаменаційних переглядів, виконання практичних форм роботи (методи графічних вправ, замальовки, етюди, пленери тощо).

Подальшого дослідження потребують педагогічні умови формування художнього смаку студентів мистецьких спеціальностей.

\section{Список використаних джерел}

Бирюков, М. Ю. (2013). Современные подходы к формированию художественного вкуса. Известия Волгоградского государственного педагогического ун-та. С. 11-15.

Естетика: підручник (2010). Л. Т. Левчук, Д. Ю. Кучерюк, В. І. Панченко. За заг. ред. Л. Т. Левчук. К.: Центр учбової літератури. 520.

Лушина, А.П. (2012). Формирование профрессионального художественного вкуса у будущих учителей изобразительного искусства средствами живописи: автореф. дисс. ... канд. пед. наук 13.00.08. Владикавказ. 23.

Мережко, Ю., Румянцева, С. (2018). Художній смак як наукова дефініція: філософсько-історичний аспект. Освітологічний дискурс. 1-2 (20- 
21). 255-266.

Парунина, Л.В. (2009). Формирование художественного вкуса будущих учителей начальных классов средствами архитектуры: авторефр. дисс. ... канд. пед.. наук 13.00.08. Сургут. 26 с.

Торчевська, Н. (2019). Застосування інформаційно-комунікаційних технологій як умова підвищення ефективності самостійної роботи студентів з курсу «Історія мистецтв». Вища школа. 1 (174). 65-72.

Торчевська, Н. (2018) Начерки та замальовки у професійній підготовці студентів закладів вищої освіти мистецького профрілю. Сучасна мистецька освіта: досвід, проблеми та перспективи: мат. Всеукр. наук.-практ. конф. 20.04.2018 р. Київ. 365-369.

Формування мистецьких уподобань учнів основної і старшої школи на уроках мистецтва та в позаурочний час : монографрія (2018). О. А. Комаровська, Н. Є. Миропольська, І. В. Руденко, С. А. Ничкало, І. С. Денисюк; за ред. Н. Є. Миропольської, О. А. Комаровської. 148.

\section{References (translated and transliterated)}

Birjukov, M.Ju. (2013). Modern approaches to the formation of artistic taste. Izvestija Volgogradskogo gosudarstvennogo pedagogicheskogo un-ta. S. 11-15. (in Russian)

Aesthetics: a textbook. (2010). L. T. Levchuk, D. Yu. Kucheryuk, V. I. Panchenko; za zag. red. L. T. Levchuk. K.: Centr uchbovoyi literatury. 520 s. (in Ukrainian)

Lushina, A.P. (2012). The formation of professional artistic taste in future teachers of fine art by means of painting : avtoref. diss. kand. ped.. nauk 13.00.08, Vladikavkaz. 23. (in Russian)

Merezhko Yu., Rumyanceva S. (2018). Artistic taste as a scientific definition: a philosophical and historical aspect. Osvitologichny ` dy skurs. 1-2 (20-21). 255-266. (in Ukrainian)

Parunina, L. V. (2009). The formation of the artistic taste of future primary school teachers by means of architecture: avtoref. diss. kand. ped.. nauk 13.00 .08 , Surgut. $26 \mathrm{~s}$. (in Russian)

Torchevs'ka, N. (2019). Application of information and communication technologies as a condition for increasing the efficiency of students' independent work in the course «History of Arts». Vy"shha shkola. 1 (174). 65-72. (in Ukrainian)

Torchevs'ka, N. (2018). Sketches and sketches in the professional training of students of higher education institutions of artistic profile. Suchasna my stecz'ka osvita: dosvid, problemy` ta perspekty 'vy': mat. Vseukr. nauk.prakt. konf., 20.04.2018 r., Ky'yiv, 365-369. (in Ukrainian)

Formation of artistic preferences of elementary and high school students in art lessons and after-school hours : monografiya. (2018). O. A. Komarovs'ka, N. Ye. My'ropol's`ka, I. V. Rudenko, S. A. Ny`chkalo, I. S. Deny`syuk; za red. N. Ye. My`ropol’s’koyi, O. A. Komarovs`koyi. 148 s. (in Russian) 